\title{
Pengetahuan Siswa Tentang Bantuan Hidup Dasar (BHD) Dengan Motivasi Menolong Korban Henti Jantung Pada Pelajar SMA
}

\author{
Syaiful $^{1(\mathrm{CA})}$, Dahlan ${ }^{2}$, Rachel Larasati ${ }^{3}$, Martiningsih $^{4}$ \\ ${ }^{1(\mathrm{CA})}$ Poltekkes Kemenkes Mataram, Jurusan Keperawatan Program Studi Diploma IV Keperawatan Bima, \\ syaiful6823@gmail.com (Corresponding Author) \\ ${ }^{2,3,4}$ Poltekkes Kemenkes Mataram, Jurusan Keperawatan Program Studi Diploma IV Keperawatan Bima
}

Genesis Naskah : Diterima 25 September 2019; $\quad$ Disetujui 12 November 2019;

Publikasi 15 November 2019

\begin{abstract}
Basic life support is emergency action for free your breath, help breathing and maintaining blood circulation without using aids. Basic life support knowledge (BLS) is knowledge and skills. Knowing the theory itself without practice makes motivation to be helpful and mentally untrained when actually dealing with real events. The aims of this study was to know the relation student knowledge of basic life support (BLS) with the motivation of helping victims of cardiac arrest at senior high school 02 in bima city on 2019. Design was used in this research was corelational. with cross sectional design. Sampling techniques using cluster sampling with 38 sample respondents. The research instrument used was a questionnaire. data analyzed using spearman rank test with significant level $(\alpha=0.05)$. The results showed that students' knowledge of BLS was mostly good with a percentage of $63,8 \%$ and motivation to help victims of cardiac arrest was mostly high a percentage of $60,5 \%$. The results of data were analyzed by correlation test using spearman rank obtained a value of $\mathrm{p}=$ value $\alpha=0,05$. Because the value of $p=$ 0.000 <value $\alpha=0.05$, then means that $\mathrm{H}_{0}$ is rejected and $\mathrm{H}_{\mathrm{a}}$ is accepted. There is a relationship between students' knowledge about basic life assistance (BLS) and the motivation to help victims of cardiac arrest at SMAN 02 Kota Bima.
\end{abstract}

\section{Keywords: Knowledge; Basic Live Support; Motivation}

\begin{abstract}
ABSTRAK
Bantuan hidup dasar merupakan tindakan darurat untuk membebaskan jalan napas, membantu pernapasan dan mempertahankan sirkulasi darah tanpa menggunakan alat bantu. Pengetahuan bantuan hidup dasar (BHD) merupakan sebuah pengetahuan dan keterampilan kerena jika hanya mengetahui teorinya saja tanpa melakukan latihan atau praktek, maka motivasi untuk menolong kurang dan mental tidak terlatih ketika benar-benar menghadapi kejadian sebenarnya. Untuk mengetahui hubungan pengetahuan siswa tentang bantuan hidup dasar (BHD) dengan motivasi menolong korban henti jantung di sman 02 kota bima. Desain yang digunakan dalam penelitian ini adalah corelational dengan metode cross sectional. Teknik pengambilan sampel dengan menggunakan cluster sampling dengan jumlah sampel 38 responden. Instrumen penelitian yang digunakan adalah kuesioner. Data dianalisis dengan menggunakan uji spearman rank dengan tingkat signifikan $(\alpha=0.05)$. Hasil penelitian menunjukkan bahwa pengetahuan siswa tentang BHD sebagian besar baik dengan persentase $63,8 \%$ dan motivasi menolong korban henti jantung sebagian besar tinggi dengan persentase $60,5 \%$. Hasil data yang dianalisis dengan uji korelasi menggunakan spearman rank diperoleh hasil nilai $p=0.000<$ nilai $\alpha=0.05$. Karena nilai $p=0.000$ $<$ nilai $\alpha=0.05$. maka artinya $\mathrm{H}_{0}$ ditolak dan $\mathrm{H}_{\mathrm{a}}$ diterima. Hasil penelitian ini menunjukkan adanya hubungan pengetahuan siswa tentang bantuan hidup dasar (BHD) dengan motivasi menolong korban henti jantung di SMAN 02 Kota Bima.
\end{abstract}

Kata Kunci : Pengetahuan; Bantuan Hidup Dasar; Motivasi 
Syaiful, Dahlan, Rachel Larasati \& Martiningsih, (2019).

\section{PENDAHULUAN}

Bantuan hidup dasar merupakan tindakan darurat untuk membebaskan jalan napas, membantu pernapasan dan mempertahankan sirkulasi darah tanpa menggunakan alat bantu. Yang termasuk tindakan bantuan hidup dasar (BHD) adalah resusitasi jantung paru (RJP) (sudiharto \& sartono, 2011). Pengetahuan bantuan hidup dasar (BHD) merupakan sebuah pengetahuan dan keterampilan kerena jika hanya mengetahui teorinya saja tanpa melakukan latihan atau praktek, maka motivasi untuk menolong kurang dan mental tidak terlatih ketika benar-benar menghadapi kejadian sebenarnya.

Kegawatdaruratan merupakan kejadian yang tak terduga yang dapat terjadi secara tiba-tiba yang memerlukan penanganan segera. Salah satu kondisi kegawatdaruratan yang dapat mengancam jiwa dan penanganan segera adalah henti jantung atau cardiac arrest. Henti jantung atau cardiac arrest adalah keadaan dimana terjadinya penghentian mendadak sirkulasi normal darah karena kegagalan jantung berkontraksi secara efektif selama fase sistolik (Hardisman, 2014). Berdasarkan WHO (World Health Organization) di Indonesia penyakit kardiovaskuler merupakan penyebab kematian nomer 1. Dari data WHO tahun 2014, disebutkan bahwa $37 \%$ angka kematian di Indonesia disebabkan karena penyakit kardiovaskuler. (World Health Organization, 2014) di Indonesia sendiri belum didapatkan data yang pasti mengenai jumlah prevalensi kejadian henti jantung di kehidupan sehari-hari atau di luar rumah sakit, namun diperkirakan 10.000 warga per tahun yang berarti 30 orang per hari mengalami henti jantung. Kejadian terbanyak dialami oleh penderita jantung koroner. Kematian yang disebabkan oleh penyakit jantung, terutama pada penyakit jantung koroner dan stroke yang diperkirakan akan terus meningkat mencapai 23,3 juta kematian pada tahun 2030 (Rikesdas, 2013). Di NTB sendiri berdasarkan data dari Riset Kesehatan Dasar tahun 2013 berdasarkan diagnosis dokter prevalensi penyakit jantung koroner sebesar $0,2 \%$ atau diperkirakan sekitar 6.405 orang, sedangkan berdasarkan diagnosis/gejala sebesar 2,1 $\%$ atau diperkirakan sekitar 67.257 orang.

Pengetahuan bantuan hidup dasar dapat membentuk motivasi dalam bersikap dan berperilaku dalam menolong siswa. Rendahnya pengetahuan dapat berdampak pada munculnya bentuk-bentuk sikap dan perilaku prososial terhadap orang disekitarnya. Sedangkan sebagai makhluk sosial hendaknya senantiasa memberikan bantuan kepada orang lain yang membutuhkan. Penilaian yang diharapkan adalah mampu meningkatkan menjadi lebih baik pengetahuan dan motivasi siswa dalam menolong terkait Bantuan Hidup Dasar (BHD). Motivasi dalam menolong khususnya korban henti jantung diharapkan akan menghasilkan keuntungan terhadap pihak lain dimana dengan adanya pengetahuan Bantuan Hidup Dasar (BHD) disertai dengan motivasi yang tinggi dalam menolong hal tersebut dapat membantu mencengah kematian dan mengurangi timbulnya kecacatan.

Berdasarkan survey awal yang dilakukan dari data yang didapatkan di SMAN 02 Kota Bima tahun 2018. Siswa anggota pramuka pernah mendapatkan pengetahuan tentang P3K. Tujuan penelitian ini untuk mengetahui "Hubungan Pengetahuan Siswa Tentang Bantuan Hidup Dasar (BHD) dengan Motivasi Menolong Korban Henti Jantung di SMAN 02 Kota Bima". 
Syaiful, Dahlan, Rachel Larasati \& Martiningsih, (2019).

\section{METODE}

Desain penelitian yang digunakan adalah deskriptif analitik dengan rancangan cross sectional. Pengambilan sampel dengan metode cluster sampling dengan jumlah sampel 38 responden, pada responden yang memenuhi kriteria inklusi: Siswa anggota pramuka aktif, Siswa yang telah mendapatkan penyuluhan tentang BHD, Sehat jasmani dan rohani, Bersedia secara sukarela untuk menjadi responden, dan Kriteria eksklusi : Siswa yang berhalangan hadir saat dilakukan penelitian. Pengambilan data menggunakan kuesioner . Kuesioner pada penelitian ini terdiri dari dua bagian yaitu bagian (A) berisi pengetahuan siswa tentang BHD dimana Kuesioner yang digunakan telah dkembangkan oleh (Rachmawaty, 2012). Responden menjawab kuesioner dengan memilih salah satu dari pilihan jawaban "Ya" atau "Tidak". Pemberian skor menggunakan skala Guttman : Benar $=1$, Salah $=0$ dengan kategori berpengetahuan baik, cukup dan kurang. Dan bagian (B) berisi pernyataan tentang motivasi dalam menolong korban kegawatdaruratan. Kuesioner dari penelitian tersebut telah dikembangkan dari kuesioner penelitian Nugroho (2013). Dalam kuesioner tersebut kuesioner diisi dengan memberikan tanda checklist $(\sqrt{ })$ dengan pilihan yang sudah ditentukan yaitu pilihan jawaban Sangat Setuju (SS), Setuju (S), Tidak Setuju (TS), Sangat Tidak Setuju (STS). Penelitian ini telah dilaksanakan pada tanggal 21 februari - 06 maret 2019 di SMAN 02 Kota Bima. Analisis Data dengan uji parametrik Spearmen menggunakan SPSS 16.

\section{HASIL DAN PEMBAHASAN}

Siswa SMAN 02 Kota Bima pada tanggal 21 Februari - 03 Maret 2019 dengan jumlah responden sebanyak 38 orang. disajikan dalam bentuk tabel distrubusi frekuensi. karakteristik responden akan diuraikan dalam data umum yaitu berdasarkan umur, jeniskelamin, dan kelas.

Tabel 1. Karakteristik responden

\begin{tabular}{clcc}
\hline No & \multicolumn{1}{c}{ Karakteristik } & Frekuensi (n) & Persentase (\%) \\
\hline 1. & Kategori Umur & & \\
& 17 Tahun & 18 & 47.4 \\
& 16 Tahun & 13 & 34.2 \\
& 15 Tahun & 7 & 18.4 \\
\hline 2. & Jenis Kelamin & & \\
& Laki-Laki & 19 & 50 \\
& Perempuan & 19 & 50 \\
\hline 3. & Kategori Kelas & & \\
& Kelas XII & 9 & 23.7 \\
& Kelas XI & 16 & 42.1 \\
& Kelas X & 13 & 34.2 \\
\hline
\end{tabular}

Table 1 menunjukan golongan umur yang terbanyak pada umur 17 tahun yaitu sebanyak 18 orang dengan persentase sebesar 47.4\%. jenis kelamin responden antara laki-laki dengan perempuan seimbang, sebanyak 19 orang dengan persentase sebesar $50 \%$, responden dengan kategori kelas yang terbanyak yaitu kelas XI 16 orang dengan persentase $42.1 \%$. 
Syaiful, Dahlan, Rachel Larasati \& Martiningsih, (2019).

Tabel 2. Distribusi Responden Berdasarkan Tingkat Pengetahuan tentang BHD di SMAN 02 Kota Bima Tahun 2019

\begin{tabular}{clccc}
\hline No & & Tingkat Pengetahuan & Frekuensi (n) & Persentase (\%) \\
\hline 1. & Baik & & 24 & 63.2 \\
2. & Cukup & 14 & 36.8 \\
3. & Kurang & & 0 & 0 \\
\hline & & Total & 38 & 100 \\
\hline
\end{tabular}

Pada tabel 2. menunjukkan distribusi pengetahuan siswa tentang Bantuan Hidup Dasar (BHD) di SMAN 02 Kota Bima mayoritas memiliki pengetahuan yang baik yaitu sebanyak 24 orang dan responden yang memiliki pengetahuan yang cukup sebanyak 14 orang. Hal ini dikarenakan para siswa yang telah terpapar materi tentang pertolongan pertama atau Bantuan Hidup Dasar serta para siswa sering melakukan kegiatan diluar sekolah seperti perkemahan atau kegiatan kepramukaan lainnya.

Selain itu tingkat pengetahuan juga dikarenakan oleh beberapa faktor diantaranya adalah faktor tingkat pengetahuan dimana dalam tingkat pengetahuan ada 6 tahapan yaitu : tahu, memahami, aplikasi, analisis, sintesis, dan evaluasi. (Budiman, dan agus, 2013). Responden yang memiliki tingkat pengetahuan yang baik itu masuk kedalam tahapan menganalisis dimana mereka tahu dan memahami tentang bantuan hidup dasar (BHD) dan berusaha mengaplikasikannya serta belajar menganalisis dari setiap kejadian yang terjadi yang memerlukan bantuan hidup dasar (BHD). Sedangkan untuk responden dengan pengetahuan cukup, mereka masuk kedalam tahapan memahami tetapi belum mampu mengaplikasikan ilmu yang diperolehnya.

Selain faktor tingkat pengetahuan terdapat juga faktor lain yang mempengaruhi pengetahuan menurut (Mubarak,2011) yaitu pendidikan, pekerjaan, umur, dan minat. Berdasarkan hasil penelitian umur responden mayoritas berumur 17 tahun yaitu sebanyak 18 responden dari 38 responden, berumur 16 tahun sebanyak 13 responden dan berumur 15 tahun sebanyak 7 responden. Menurut WHO (World Health Organization) umur 15-17 tahun termasuk dalam kategori usia remaja dimana usia remaja memiliki perkembangan kognitif atau mengalami perkembangan penalaran dan kemampuan berfikir untuk memecahkan persoalan yang dihadapi berdasarkan pengalaman langsung. Selanjutnya pengetahuan juga dipengaruhi oleh minat, dimana dengan adanya minat menjadikan seseorang untuk mencoba dan menekuni suatu hal sehingga mereka dapat memperoleh pengetahuan lebih mendalam. (Mubarak, 2011).

Tabel 3. Distribusi Responden Berdasarkan Tingkat Motivasi Menolong Korban Henti Jantung di SMAN 02 Kota Bima Tahun 2019

\begin{tabular}{ccccc}
\hline No & & Tingkat Motivasi & Frekuensi (n) & Persentase (\%) \\
\hline 1. & Tinggi & & 23 & 60.5 \\
2. & Sedang & & 15 & 39.5 \\
3. & Kurang & & 0 & 0 \\
\hline & & Total & 38 & 100 \\
\hline
\end{tabular}

Pada tabel 3. menunjukkan distribusi frekuensi motivasi pada siswa anggota Pramuka di SMAN 02 Kota Bima dalam memberikan pertolongan pada korban henti jantung (kegawatdaruratan) terbanyak dengan motivasi tinggi sebanyak 23 responden sedangkan dengan motivasi sedang sebanyak 15 responden. 
Peneliti berpendapat bahwa motivasi pada siswa anggota pramuka dalam memberikan pertolongan pada korban henti jantung (kegawatdaruratan) sangat penting karena disatu sisi mereka adalah anggota pramuka dimana dalam keanggotaan pramuka harus berpegang teguh pada janji Tri Satya dimana salah satu janjinya adalah menolong sesama. Selain itu juga mereka berpengalaman mengikuti kegitaan kepramukaan di luar sekolah sehingga secara tidak langsung hal tersebut dapat menambah atau meningkatkan perilaku prososial atau prilaku menolong dari siswa tersebut.

Faktor-faktor yang mempengaruhi motivasi terbagi menjadi 2 faktor (Siagan,2006), yaitu faktor internal yang terdiri dari harga diri, tanggung jawab, keinginan, harapan dan suasana hati sedangkan faktor eksternal terdiri dari faktor lingkungan, kelompok, organisasai yang diikuti, teman sebaya, daya tarik dan orang-orang disekitar.

Dari hasil penjelasan diatas menunjukkan motivasi pada siswa sebagian besar memiliki motivasi tinggi pada penelitian ini dikategorikan dari kemampuan yang dimiliki oleh siswa dalam memahami dan menganalisis ilmu pengetahuan tentang bantuan hidup dasar (BHD), hal ini dibuktikan dari hasil tingkat pengetahuan siswa tentang bantuan hidup dasar (BHD) dikategorikan baik jadi akan mempengaruhi motivasi yang tinggi pada siswa dalam menolong korban henti jantung (kegawatdaruratan). Motivasi tinggi pada siswa dalam menolong korban henti jantungdikarenakan mereka terlibat dalam organisasi kepramukaan dimana salah satu tugas mereka adalah menolong sesama dengan tulus bertanggungjawab. Penelitian ini sejalan dengan penelitian yang dilakukan oleh Winarto Rudi (2017) terdapat hubungan antara tingkat pengetahuan tentang pertolongan pertama pada kecelakaan dengan motivasi menolong kecelakaan lalu lintas pada remaja di SMK Binakarya 1 Karanganyar karena pada penelitian yang diteliti oleh Winarto Rudi bahwa siswa di SMK Binakarya 1 Karanganyar memiliki tingkat pengetahuan yang baik tentang pertolongan pertama pada kecelakaan sehingga memiliki motivasi yang tinggi dalam menolong pada kecalakaan lalu lintas.

Hasil penelitian juga terdapat siswa yang memiliki motivasi yang sedang, hal tersebut dipengaruhi oleh faktor instrinsik yaitu dimana siswa memiliki keinginan yang positif, harapan yang tinggi, namun mereka memiliki keyakinan yang rendah bahwa dirinya dapat bersosialisasi dan mampu menyelesaikan persoalan yang dihadapi. Mereka ragu dalam mengaplikasikan pengetahuan yang telah mereka peroleh. Dan sebagian besar siswa yang memiliki motivasi sedang adalah siswa yang memiliki pengetahuan yang cukup.

Tabel 4. Tabulasi Silang Antara Hubungan Pengetahuan Siswa Tentang BHD Dengan Motivasi Menolong Korban Henti Jantung di SMAN 02 Kota Bima Tahun 2019

\begin{tabular}{|c|c|c|c|c|c|c|c|c|}
\hline \multirow{3}{*}{ Pengetahuan } & \multicolumn{6}{|c|}{ Motivasi } & \multirow{2}{*}{\multicolumn{2}{|c|}{ Jumlah }} \\
\hline & \multicolumn{2}{|c|}{ Tinggi } & \multicolumn{2}{|c|}{ Sedang } & \multicolumn{2}{|c|}{ Kurang } & & \\
\hline & $\mathbf{n}$ & $\%$ & $\mathbf{n}$ & $\%$ & $\mathbf{n}$ & $\%$ & \multicolumn{2}{|c|}{$\begin{array}{l}\text { Jumlah } \\
\text { n } \%\end{array}$} \\
\hline Baik & 20 & 52.6 & 4 & 10.5 & 0 & 0 & 24 & 63.2 \\
\hline Cukup & 3 & 7.9 & 11 & 28.9 & 0 & 0 & 14 & 36.8 \\
\hline Kurang & 0 & 0 & 0 & 0 & 0 & 0 & 0 & 0 \\
\hline \multirow[t]{2}{*}{ Jumlah } & 23 & 60.5 & 15 & 39.5 & 0 & 0 & 38 & 100 \\
\hline & Spec & & $\mathrm{p}=0$ & & $\mathrm{r}=0$ & & & \\
\hline
\end{tabular}


Berdasarkan data tabulasi silang antara pengetahuan bantuan hidup dasar dengan motivasi menolong koban henti jantung diperoleh hasil dari responden yang berjumlah 38 orang yaitu responden yang memiliki pengetahuan baik dan motivasi yang Tinggi sebanyak 20 orang (52.6\%), responden yang berpengetahuan baik dan motivasi yang Sedang berjumlah 4 orang $(10,5 \%)$, responden dengan pengetahuan Cukup dan motivasi Tinggi berjumlah 7 orang $(7,9 \%)$ sedangkan responden dengan pengetahuan Cukup dan motivasi Sedang berjumlah 11 orang $(28,9 \%)$.

Pengetahuan dan keterampilan dalam bantuan hidup dasar (BHD) sangat penting untuk diketahui dan diterapkan oleh anggota pramuka dalam upaya menolong sesama manusia dimana sebagai seorang pencinta alam kondisi alam seringkali tidak dapat diduga dan sangat mungkin untuk terjadi kecelakaan yang tidak diharapkan.

Motivasi terbagi atas motivasi intrinsik dan motivasi ekstrinsik. Motivasi intrinsik merupakan motivasi yang yang berfungsi tanpa adanya rangsangan dari luar. Motivasi instrinsik merupakan motivasi yang timbul dari dalam diri seseorang untuk menjadi lebih baik, dan lebih mengacu pada hubungan siswa anggota pramuka dengan tugasnya. motivasi ekstrinsik merupakan motivasi yang berfungsi dengan adanya faktor dorongan dari luar individu. (Sardiman,2009).

Pengetahuan seseorang akan mempengaruhi bagaimana seseorang tersebut termotivasi untuk bertingkah laku sesuai dengan yang pernah dipelajarinya. Semakin banyak seseorang mempelajari atau mengetahui sesuatu hal maka ia akan lebih termotivasi untuk mengaplikasikan apa yang pernah ia pelajari. Toyyibah (2014) dalam jurnal penelitiannya mengatakan bahwa remaja yang berada dalam perkembangan pada ukuran tubuh, kekuatan, psikologis, kemampuan bereproduksi, mudah untuk termotivasi dan cepat belajar diharapkan dapat menjadi bysander dilingkungannya masing-masing dan karakteristik tersebut dapat ditemukan pada remaja tingkat Sekolah Menengah Atas.

Pengetahuan yang diperoleh dalam meningkatkan motivasi dapat diperoleh dari proses belajar dengan pemanfaatan media yang digunakan responden. Hal ini juga diungkapkan oleh Setiawati \& Dermawan (2008) bahwa salah satu jenis motivasi yang dilihat dari dasar pembentukannya adalah motivasi yang dipelajari yang berarti motivasi ini akan ada dan berkembang karena adanya keingintahuan seseorang dalam proses pembelajaran.

Selain dari penjelasan diatas, faktor yang mempengaruhi adanya hubungan pengetahuan bantuan hidup dasar dengan motivasi menolong itu karena para siswa anggota pramuka telah mendapatkan materi penyuluhan tentang pertolongan pertama atau bantuan hidup dasar sehingga dari situlah akan menumbuhkan rasa motivasi dalam diri siswa tersebut untuk menolong meskipun motivasi tersebut ada yang tinggi maupun sedang. Hasil penelitian yang dilakukan peneliti sejalan dengan penelitian Tri Nurhilawati,martiningsih,dkk. (2017) dimana terdapat hubungan yang kuat antara pengetahuan bantuan hidup dasar dengan keterampilan dalam tindakan recovery position pada kader TSBK di Kota Bima. Sedangkan hasil penelitian yang telah dilakukan oleh peneliti sendiri menunjukkan adanya hubungan pengetahuan responden dengan moivasi menolong korban henti jantung dengan hasil sebesar 0.000 , karena nilai Sig (2-tailed) 0.000 kurang dari $p$-value $\leq 0.05$ artinya ada hubungan yang signifikan (berarti) antara variabel pengetahuan Bantuan Hidup Dasar (BHD) dengan motivasi. Berdasarkan hasil uji Spearman Rank juga diperoleh angka koefisien korelasi sebesar 0.611**. Dimana artinya tingkat 
kekuatan hubungan (korelasi) antara variabel pengetahuan Bantuan Hidup Dasar (BHD) dengan motivasi adalah sebesar 0.611 atau korelasi kuat DENGAN jenis hubungan searah), dengan demikian dapat diartikan bahwa semakin ditingkatkan pengetahuan tentang bantuan hidup dasar maka semakin tinggi pula tingkat motivasi siswa dalam menolong korban henti jantung.

\section{KESIMPULAN}

Pengetahuan siswa anggota pramuka tentang bantuan hidup dasar di SMAN 02 Kota Bima sebagian besar berpengetahuan Baik. Dan mayoritas motivasi pada siswa anggota pramuka di SMAN 02 Kota Bima dalam memberikan pertolongan pada korban henti jantung (kegawatdaruratan) sebagian besar dalam motivasi kategori tinggTerdapat hubungan antara pengetahuan siswa tentang bantuan hidup dasar (BHD) dengan motivasi menolong korban henti jantung di SMAN 02 Kota Bima.

\section{DAFTAR PUSTAKA}

Alhidayat, N,A., Rahmat, A., Simunati. (2013). Hubungan Tingkat Pengetahuan Perawat Instalasi Gawat Darurat tentang Pengkajian terhadap Pelaksanaan Tindakan Life Support di Rumah Sakit Pelamonia Makassar. Vol. 2, No. 4

American Heart Association (AHA) (2005). Basic Life Support Health Care Provider Pre-test. (sitase) http://www.clinicalnursinginstitue.org pada tanggal 19 Januari 2017 jam 12.30 WITA

American Heart Association (AHA) (2010). Basic Life Support: Guidelines for cardiopulmonary Resucitation and Emergency Cardiovaskuler Care, (sitase) http://circ.ahajournals.org tanggal 19 Januari 2017 jam 12.43 WITA

American Heart Association (2015). Fokus Utama Pembaruan Pedoman American Heart 2015 untuk CPR dan ECC. (sitase) http://www.eccguidelines.heart.org pada tanggal 26 Januari 2017 jam 14.15 WITA

Dinas Kesehatan (Desember,2013) (sitase) http://dinkes.sambas.go.id tanggal 26 Januari 2017 jam 15.20 WITA

Erawati, S. (2015). Tingkat Pengetahuan Masyarakat Tentang Bantuan Hidup Dasar (BHD) Di Kota Administrasi Jakarta Selatan. Skripsi, Universitas Islam Negeri Sarif Hidayatullah , Program Studi Ilmu Keperawatan Fakultas Kedokteran Dan Ilmu Kesehatan, Jakarta.

Fajarwati, H. (2012). Basic Life Support tim bantuan medis FK UII. (Sitase) http://medicine.uii.ac.id tanggal 20 Juni 2017

Hardisman. (2014). Gawat Darurat Medis Praktik. Yogyakarta: Gosyen Publishing.

Hasanah, U. N. (2015). Hubungan Tingkat Pengetahuan Dengan Ketrampilan Perawat Dalam Melakukan Tindakan Bantuan Hidup Dasar (BHD) Di RSUD Karanganyar. Skripsi, Stikes Kusuma Husada, Program Studi S-1 Keperawatan, Surakarta.

Trinurhilawati, Martiningsih, Rini Hendari, Ade Wulandari. (2019). Pengetahuan Bantuan Hidup Dasar Dan Keterampilan Tindakan Recovery Position Pada Kader Siaga Bencana. Jurnal Keperawatan terpadu, no 1, Volume 1. April 2019.

Mulyadi. (2016). Pengaruh Penyuluhan dan Simulasi Bantuan Hidup Dasar (BHD) terhadap Tingkat Pengetahuan Siswa SMAN 9 Kota Manado, 2-5. 
Nursalam. (2008). Konsep dan penerapan metodologi penelitian ilmu keperawatan : Pedoman skripsi, tesis, dan instrumen penelitian (2 ed.). Jakarta: Salemba Medika.

Nursalam. (2014). Metodologi Penelitian Ilmu Keperawatan: Pendekatan Praktis. Edisi 3. Jakarta: Salemba Medika

Pro Emergency. (2011). Basic Trauma Life Support. Cibinong: Pro Emergency Resuscitation Council (UK). (2010, Oktober). (sitase) http://www.resus.org.uk pada tanggal 19 Januari 2017

Rachmawaty, S. (2012). Gambaran Tingkat Pengetahuan Mahasiswa Kesehatan Dan Non-Kesehatan Universitas Indonesia Tentang Tekhnik Resusitasi Jantung Paru (RJP) Pada Orang Dewasa. Skripsi, Universitas Indonesia, Fakultas Ilmu Keperawatan Program Sarjana Reguler, Jakarta.

Supriyantoro. (2011). Kebijakan Kemenkes dalam Sistem Penanggulangan Gawat Darurat Terpadu (SPGDT) dan Bencana.

Wawan A \& Dewi M. (2011). Teori dan Pengukuran Pengetahuan, Sikap dan Perilaku. Yogyakarta: Muha Medika.

Wijaya, I. S., Asri Dewi, N. M., \& Yudhawati, N. S. (2016, Agustus 29-30). Tingkat Pengetahuan Bantuan Hidup Dasar Pada Masyarakat Di Kecamatan Denpasar Utara. 319-328. 